\title{
INTIMATE SELECTED REMARKS FOLLOWING THE COST ACTION
}

\author{
DANUTA J. MICHCZYŃSKA \\ GADAM Centre of Excellence, Institute of Physics - CSE \\ Silesian University of Technology \\ Konarskiego 22B, 44-100 Gliwice, Poland \\ danuta.michczynska@polsl.pl \\ Member of the Management Committee of the Action
}

LESZEK STARKEL

Institute of Geography and Spatial Organization, Polish Academy of Sciences

Św. Jana 22, 31-018 Kraków, Poland

starkel@zg.pan.krakow.pl

COST Action ES0907 INTIMATE - INTegrating Ice core, MArine and TErrestrial records (60 000 to 8000 years ago), as chaired by Dr. Sune Olander Rasmussen from the Niels Bohr Institute at the University of Copenhagen, came to an end on 23 rd June 2014. The main aim of this Action was to reconstruct past abrupt and extreme climate changes over the aforementioned period, by facilitating integration of ice core, marine, and terrestrial palaeoclimate records and using the combined data in climate models to better understand the mechanisms and impact of change, thereby reducing the uncertainty of future prediction.

This Action has a reach history extending back to the early '90s. (for details please visit: http://cost-es0907.geoenvi.org/the-action/intimate-history), and is an example of how collaboration between scientists from different disciplines and countries contributes to a better understanding of climate change. The Action brought 
together scientists working on separate issues in different national and international projects, initiatives and networks. These include ACER (Abrupt Climate Changes and Environmental Responses), the PAGES (Past Global Changes) Varve Working Group, the Subcommission on Quaternary Stratigraphy (International Commission on Stratigraphy), the International Union for Quaternary Research (INQUA), the International Radiocarbon Calibration community (IntCal), Climate Variability and Predictability (CLIVAR) and many other. Altogether almost 270 scientists were involved in the Action. The project was organized under 4 Working Groups, on:

- Dating and Chronological Modelling;

- Quantification of Past Climate;

- Modelling Mechanisms of Past Change;

- Climate Impacts.

The Memorandum of Understanding (MoU) on the Action was signed by 23 countries. Poland officially joined the Action on December 7th, 2011, but representatives of Poland had in fact already taken part in the first Workshop entitled Towards High-Precision Chronologies, which was organised at the German Research Centre for Geosciences GFZ in Potsdam on 7th-9th February, 2011.

One of the valuable achievements of the Action is the establishment of a truly pan-European research network, as well as a close collaboration between early-stage and established scientists, as was expressed through the organisation of numerous Workshops, training schools and Short-Term Scientific Missions (STSMs). One of the schools was jointly organised by the GADAM Centre (Institute of Physics - CSE, Silesian University of Technology, Gliwice, Poland) and GFZ Potsdam (Germany). Its name was the "Summer Training School on Dating Methods and Their Applications". The School, which was organised in both Potsdam and Gliwice, took place between $6^{\text {th }}$ and $13^{\text {th }}$ September 2012, and was attended by 21 participants from 10 countries. Exercises and visiting labs were pointed to as the most fruitful part of the School, and the students' opinion that practical parts could be broadened should a new School be run was of assistance when it came to the organising of the next two "INTIMATE Example" training schools in a new way - as multidisciplinary research focused on training.

During the lifetime of the Action almost 20 different Workshops were organized. For scientists from the Central-Eastern part of Europe, two of these were of particular importance. The first - the INTIMATE Workshop on Terrestrial Records from Eastern Europe was organized in Cluj-Napoca, Romania (6 $6^{\text {th }} 9^{\text {th }}$ March, 2013), and helped bring together scientists from Eastern and Central Europe with a view to a start being made to the gathering of relevant palaeoclimatic data in a standardised form, the identification of new research directions that would fill in the ever-present "white spots" in our knowledge, and the establishment of new partnerships for future studies. The Prepared publication of Feurdean et al. (2014) is a first important quantifiable fruit of the collaboration established. The second workshop - Climate impacts on sedimentary environments was organized in Utrecht, The Netherlands 
(30 $0^{\text {th }}$ September $-1^{\text {st }}$ October 2013). In the course of this workshop, a team of six persons from Poland (Starkel L., Michczyńska D.J. and Gębica P.), Hungary (Kiss T.), Russia (Panin A.V.) and Romania (Perşoiu I.) presented a preliminary, regional synthesis on Climate fluctuations reflected in the evolution of fluvial systems of Central-Eastern Europe (60-8 ka cal BP). This topic was later presented in a final form (Starkel et al. 2014, submitted) at the INTIMATE Open Workshop and COST Action ES0907 Final Event in Zaragoza, Spain (15 $15^{\text {th }} 21^{\text {st }}$ June 2014). Key facts from this synthesis are presented in a separate chapter.

The main results of INTIMATE activities have been published in a special issue of Quaternary Science Reviews (2012), and are also being published in a second special (2014) issue of the same journal, as well as in two special (2014) issues of Quaternary International. The total number of papers arising from the Action exceeds 50. Among the publications, particularly noteworthy is the INTIMATE event stratigraphy published in 2012 (Blockley et al. 2012), and its extension (Rasmussen et al. 2014 in press).

Although the Action has now ended, all members of the Management Committee agreed to continue the collaboration by:

- maintaining INTIMATE as a "brand name" that represents the same guiding principles having application thus far;

- keeping INTIMATE as an open network with strong involvement of early-stage researchers;

- building and maintaining network communication infrastructure: web, e-mail lists;

- organising and/or coordinating events on all scales: an EGU session, topical and open workshops ( $\sim 1$ year-1), and training schools;

- managing the database and supporting the addition of further records;

- identifying and fertilising future options for collaboration and funding opportunities.

Nominated as the new chair of the INTIMATE community was Christine Lane of the Research Laboratory for Archaeology and the History of Art at Oxford University.

\section{KEY FACTS FROM THE SYNTHESIS ON CLIMATE FLUCTUATIONS REFLECTED IN THE EVOLUTION OF FLUVIAL SYSTEMS OF CENTRAL-EASTERN EUROPE (60-8 KA CAL BP)}

The CE Europe area as defined comprises two parts characterised by a more continental climate (the presence of permafrost). The southern part is dominated by young mountain ranges separated by subsiding basins, while the northern one (as partly invaded by the Scandinavian ice sheet) has extensive lowlands draining into the Baltic Sea, or else to the Black Sea in the SE part. These facts, including also fluctuations of sea level, played an important role in the evolution of fluvial systems. Despite the complicated dependence on many factors, the main climatic phases recorded in 
Greenland ice cores (Rasmussen et al. 2008) could also be recognised in the fluvial records. The climatic continentality with permafrost facilitated the preservation of some boreal trees. The general concept of palaeogeographic changes for this region during the Vistulian had been presented at an earlier stage by Starkel (1977), and the terrace system for the whole course of the Vistula valley by Starkel et al. (2007). The most detailed investigations, with many dozens of ${ }^{14} \mathrm{C}$ and luminescence dating results, were documented for the Subcarpathian Basins (Gębica et al., 2014), along the Tisza rivers (Kiss et al. 2014), and along tributaries of the Neman and Dnieper (Panin et al. 2014).

The alluvia of the older Pleniglacial (before $60 \mathrm{ka}$ cal BP) are usually buried under younger deposits, and form the lower members of the Vistulian terraces in the mountains. The long Interpleniglacial (58-28 ka cal BP) is represented in the mountains and plateaus by thick slope deposits interdigitating with alluvia rich in organic remains (peat layers). Large alluvial fans extend out at the outlet from the mountains. In these fans, $2-3$ cuts and fills were registered at several localities, and are especially well-recognised in Poland's Sandomierz Basin (Gębica et al. 2014). Rapid cooling and an increase in continentality caused expansion of permafrost and a distinct change to downcutting, which preceded the maximum advance of the Scandinavian ice sheet (Starkel et al. 2007) and led to the covering of the interpleniglacial alluvial plains by thick younger loess. That Interpleniglacial period, with frequent climatic fluctuations, was the time of deposition of deluvial and colluvial silts and sands up to $20 \mathrm{~m}$ thick, and in smaller valleys dissecting loess plateaus. Only in the subsiding Pannonian Basin is a permanent trend towards aggradation to be observed.

In turn, at the time the ice sheet reached its maximum extent, ice-dammed lakes and ice-marginal valleys were formed. Glaciofluvial fills were also formed during the transfluence into the Black Sea (area). Braided rivers in the mountain forelands formed incised lower alluvial fans. Strong aeolian activity caused the formation of dune fields, especially in the western part of the Pannonian Basin. Wind activity was very high in some intramountain areas, in which deflation eroded shallow deposits.

During the period of ice-sheet recession, gradual downcutting, supported by glacioisostatic uplift, took place. The erosion extended down several tens of metres below the present-day Baltic Sea level, and was stopped by the Littorina transgression in the mid-Holocene. From about $15 \mathrm{ka}{ }^{14} \mathrm{C}$ BP (18 ka cal BP), a gradual expansion of boreal trees from the East took hold, coinciding with the onset of a reduction in loads of sediment being carried.

Only the largest rivers, like the Danube and the Tisza preserved meandering channels for the whole time in the subsiding depressions. In most river valleys gradual change from braided channels to meandering ones was typical. There were two warmer phases during which the formation of great palaeomeanders took place: 19-17 ka cal BP and 14.7-11.7 ka cal BP. The large palaeomeanders of the older phase are developed over boreal forests-steppes of northern Ukraine and southern Russia (Sidorchuk et al. 2011), along tributaries of the Tisza (Gábris et al. 2012). After the next cool phase there 
followed a second warmer phase of the Late Glacial, during which great meanders developed (these being better expressed north of the Carpathians, where the advance of forest stabilized the outflow). That system during the Younger Dryas changed to stable discharges reflected in small scale palaeomeanders.

Much greater diversity has been registered following the Upper Pleniglacial, on the alluvial fans in permanently subsiding areas. Here frequent channel avulsions reflected changes in the hydrological regime of the headwater area.

During the early Holocene, under dense forest, relatively limited discharge and sediment loads were characteristic of rivers, especially in the Pannonian Basin, which was still occupied partly by steppe vegetation. The climate changed about $8.5{ }^{14} \mathrm{C}$ ka BP (9.5 ka cal BP), during which time a phase of frequent floods and the expansion of deciduous trees ensued, as reflected in minerogenic layers in peatbogs and avulsions of rivers.

\section{REFERENCES}

Blockley S.P.E., Lane C.S., Hardiman M., Rasmussen S.O., Seierstad I.K., Steffensen J.P., Svensson A., Lotter A.F., Turney C.S.M., Bronk Ramsey C., INTIMATE members, 2012. Synchronisation of palaeoenvironmental records over the last 60,000 years, and an extended INTIMATE event stratigraphy to 48,000 b2k, Quaternary Science Reviews, 36, 2-10.

Feurdean A., Perşoiu A., Stevens T., Tanšău I., Magyari E., Onac B., Marković S., Andrič M., Connor S., Fărcaş S., Gałka M., Guadeny T., Hoek P., Kolaczek P., Kunes P., Lamentowicz M., Marinova E., Michczyńska D., Perşoiu I., Płóciennik, Slowinski, Stancikaite M., Sumegi P., Svensson A., Tămaş T., Timar A., Tonkov S., Toth M., Veski S., Willis K., Zernitskaya V., 2014, Climate variability and associated vegetation response throughout Central and Eastern Europe (CEE) between 60 and $8 \mathrm{ka}$, Quaternary Science Reviews 10.1016/j.quascirev.2014.06.003, in press.

Gábris Gy., Horváth E., Novothny Á., Ruszkiczay-Rüdiger Zs., 2012, Fluvial and aeolian landscape evolution in Hungary - results of the last 20 years research, Netherlands Journal of Geosciences, 91, 111-128.

Gębica P., Starkel L., Michczyńska D.J., 2014, Fluvial history of Subcarpathian Basins (Poland) during the last cold stage (60-8 cal ka BP), Quaternary International, submitted.

Kiss T., Hernesz P., Sümeghy B., Györgyövics K., 2014, Evolution of the fluvial system of the Pannonian Basin - fluvial processes in a subsiding area since the beginning of the Würm, Quaternary International, submitted.

Panin A.V., Adamiec G., Arslanov K.A., Bronnikova M.A., Filippov V.V., Sheremetskaya E.D., Zaretskaya N.E., Zazovskaya E.P., 2014, Absolute chronology of fluvial events in the upper Dnieper river system and its palaeogeographic implications, Geochronometria, DOI 10.2478/s13386-013-0154-1.

Rasmussen S.O., Bigler M., Blockley S.P.E., Blunier T., Buchardt S.L., Clausen H.B., Cvijanovic I., Dahl-Jensen D., Johnsen S.J., Fischer H., Gkinis V., Guillevic M., Hoek W.Z., Lowe J.J., Pedro J., Popp T., Seierstad I.K., Steffensen J.P., Svensson A.M., Vallelonga P., Vinther B.M., 
Walker M.J.C., Wheatley J.J., Winstrup M., 2014, A stratigraphic framework for robust naming and correlation of abrupt climatic changes during the last glacial period based on three synchronized Greenland ice core records, Quaternary Science Review, $\mathrm{http}: / / \mathrm{dx}$.doi.org/10.1016/j.quascirev.2014.09.007, in press.

Rasmussen S.O., Seierstad I.K., Andersen K.K., Bigler M., Dahl-Jensen D., Johnsen S.J., 2008, Synchronization of the NGRIP, GRIP, and GISP2 ice cores across MIS 2 and palaeoclimatic implications, Quaternary Science Reviews, 27, 18-28.

Sidorchuk A., Panin A., and Borisova O., 2011, Surface runoff to the Black Sea from the East European Plain during Last Glacial Maximum-Late Glacial time, [in:] Buynevich I., Yanko-Hombach V., Gilbert A.S., and Martin R.E., (eds), Geology and Geoarchaeology of the Black Sea Region: Beyond the Flood Hypothesis, Geol. Soc. Am. Spec. Pap, 473, $1-25$.

Starkel L., 1977, The palaeogeography of mid-and east Europe during the last cold stage, with west European comparisons, Phil. Trans. Royal Soc., London, B, 280, 351-372.

Starkel L., Gębica P., Superson J., 2007, Last Glacial-Interglacial cycle in the evolution of river valleys in southern and central Poland, Quaternary Science Reviews, 26, 2924-2936.

Starkel L., Michczyńska D.J., Gębica P., Kiss T., Panin A.V., Perşoiu I., 2014, Climate fluctuations reflected in the evolution of fluvial systems of Central-Eastern Europe (60-8 ka cal BP), Quaternary International, submitted.

Web sites:

http://cost-es0907.geoenvi.org/the-action/intimate-history

http://cost-es0907.geoenvi.org/activities/intimate-events

Memorandum of Understanding INTIMATE Action: http://costes0907.geoenvi.org/resources/ useful-files-public

Rasmussen S.O. and MC Members, 2014, Minutes from the Management Committee and Final Evaluation Meeting COST Action no. ES0907, http://cost-es0907.geoenvi.org/attachments/ article/106/Slides $\% 20$ and $\% 20$ minutes $\% 20$ from $\% 20$ INTIMATE $\% 20$ COST $\% 20$ Action $\% 20$ ES0907\%20final\%20MC\%20meeting\%20June\%2018th\%202014.pdf 